\title{
Changes in traditional building materials: the case of gypsum in Northern Spain
}

\author{
Pedro Bel-Anzué ${ }^{1} \cdot$ Kerstin Elert ${ }^{1}$ (1)
}

Received: 8 July 2021 / Accepted: 1 September 2021 / Published online: 30 September 2021

(c) The Author(s) 2021

\begin{abstract}
The rural and monumental architecture of Northern Spain gives testimony of the wide-ranging constructive possibilities of traditional gypsum for exterior and structural applications. However, today, gypsum is only used for finishing purposes. By combining a bibliographic review with local visits/interviews and experimental gypsum calcinations, we were able to document traditional processing methods and analyze the factors responsible for the decline of exterior and structural gypsum use. Obtained results are also valid for other European countries and contribute to a better understanding of the technical peculiarities of traditional gypsum, hopefully reviving traditional processing techniques to produce compatible and sustainable conservation materials.
\end{abstract}

Keywords Gypsum calcination · Quarry · Kiln · Gypsum processing

\section{Introduction}

Although today, gypsum is mainly used for decorative or finishing purposes, it has been historically applied as a structural material for columns, load-bearing walls, slabs, structural ribs, arches, and vaults (Mileto et al. 2011; Sanz Arauz and Villanueva Domínguez 2004; Vegas et al. 2010). According to Kingery et al. (1988), the architectural use of gypsum can be traced back to the Late Epipaleolithic Natufian culture (10,300-8500 B.C.). Gypsum was also the preferred binder for masonry mortars and decorative plasters in Ancient Egypt and Greece (Lucas and Harris 1962). Moreover, many examples of great architectural wealth built with gypsum can be found in the Middle East, where gypsum played an important role in the traditional architecture and was used either directly as blocks or, after calcination, as mortars and plasters for façades, floors, and structural elements (Elsen 2006; Rodríguez-Navarro 2012; Vegas et al. 2010).

Spain, as the seventh largest gypsum producer in the world (second largest in Europe; Reichl et al. 2014), has a gypsum-bearing outcrop area of $21,700 \mathrm{~km}^{2}$, which

Kerstin Elert

kelert@ugr.es

1 Department of Mineralogy and Petrology, University of Granada, Fuentenueva S/N, 18071 Granada, Spain represents $\sim 4.2 \%$ of the country's total area (Herrero et al. 2013). Gypsum outcrops are mainly concentrated in the Mediterranean half of the peninsula. This region is known as the "gypsiferous Spain" (Riba Arderiu and Macau Vilar 1962), encompassing $58.5 \%$ of the countries territory including the autonomous communities of Aragon, Catalonia, Valencia, Region of Murcia, and some parts of Castile and Leon, Castile-La Mancha, and Andalusia, where gypsum played an important role in the traditional architecture (Gárate Rojas 1999; La Spina and Grau Giménez 2020b).

The present study focuses on the autonomous community of Aragon (with the provinces of Huesca, Zaragoza and Teruel), a region with large gypsum outcrops, showing significant differences in population density and degree of industrialization due to geographic peculiarities. The abundant availability of gypsum translates into its great presence in the traditional Aragonese monumental and popular architecture. The examples shown in Fig. 1 reflect the material's wide-ranging constructive possibilities, including decorative and structural applications.

Even though gypsum remained an important building material in the popular architecture in many rural areas of Aragon, where significant changes in gypsum technology did not occur until the second half of the twentieth century (Berzosa 1976), in general, it ceased to be used for structural application, floors and facades, and became a material 
Fig. 1 Decorative and structural gypsum use: a decorative plasterwork, "Aljaferia" palace, eleventh century (Zaragoza, Zaragoa); b exterior plasterwork, "Los Luna" palace, fourteenth to sixteenth century (Daroca, Zaragoza); c arches built with gypsum stone masonry, rammed earth, and gypsum mortar (La Ginebrosa, Teruel), and $\mathbf{d}$ buttresses made of gypsum (Fuentes de Jiloca, Zaragoza)
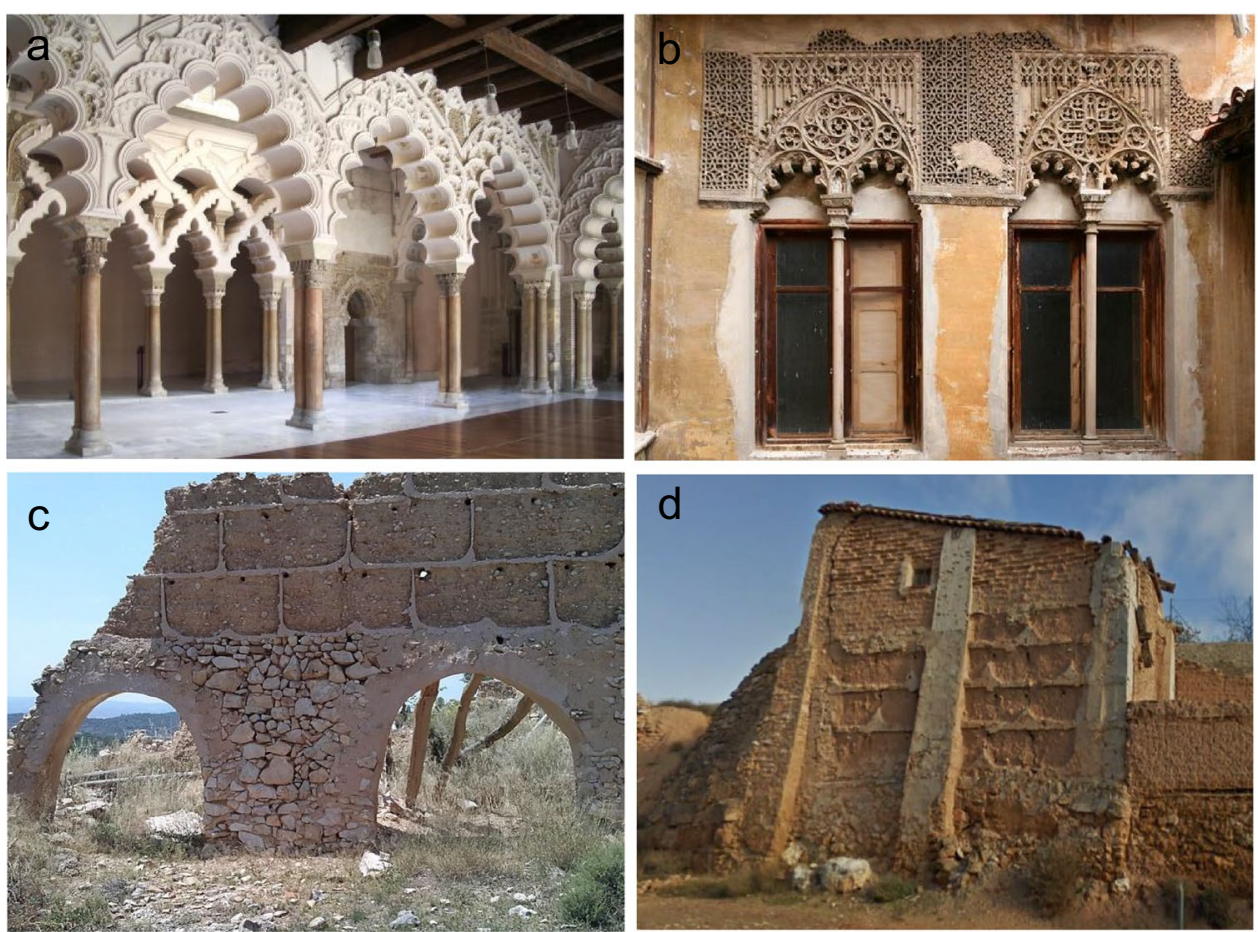

considered mostly for indoor decorative and finishing purposes (Bel-Anzué et al. 2017).

The aim of this investigation is to establish a chronological timeline for the gypsum technology and to study in detail the factors (i.e., technological, geographic, and socioeconomic aspects) responsible for the decline of the structural use of gypsum in the traditional architecture. Recent national and international studies (Dariz and Schmid 2019; La Spina et al. 2013; Le Dantec 2016; Wende et al. 2010) revealed quite a few similarities with other Spanish regions and European countries regarding the changes in gypsum technology and construction systems, the research outcome of this study being thus very well applicable to the rest of the "gypsiferous Spain" and beyond.

The research methodology applied here combines a bibliographic review, local visits and interviews, as well as experimental gypsum calcinations in traditional kilns. This holistic approach enabled a detailed documentation and analysis, which contributes to a better understanding of the technical peculiarities of this historic building material and, hopefully, will result in a revival of traditional manufacturing techniques in order to obtain a suitable product for structural use in sustainable new constructions (i.e., locally calcined, traditional gypsum requires lower calcination $T$ and has a lower carbon footprint as compared to Portland cement) and compatible conservation mortars and plasters for architectural heritage interventions (Bel-Anzué et al. 2017; Middendorf 2002; Schlütter et al. 2010). The latter being of outmost importance, considering that more recently, a lack of an in-depth knowledge regarding the properties of traditional gypsum has resulted in several unsuccessful restoration interventions in the case of important monuments and buildings (e.g., rehabilitation of the tower of Ivorra, Lleida), evidencing the incompatibility of modern replacement materials such as industrial gypsum and Portland cement.

\section{Objectives}

This investigation has been undertaken in order to achieve the following three objectives: (i) to establish a chronological timeline of the architectural use of traditional gypsum in Aragon; (ii) to give a detailed description of the traditional gypsum technology and changes suffered during the twentieth century, considering all processing steps including the selection of quarries, extraction methods, type of kiln and combustion material, calcination conditions, and means of crushing, storage and transport to the construction site; and (iii) to identify factors leading to changes in gypsum use, including technical and social-economical aspects, demography, and changes in construction systems.

\section{Methodology}

The research methodology combines a bibliographic review, personal communications with administrations, cultural associations, and ethnographers, as well as local visits and interviews. A toponymic search was carried out in order 
Fig. 2 Map of the community of Aragón, showing the 147 visited municipalitiese and 89 bibliographically documented municipalities

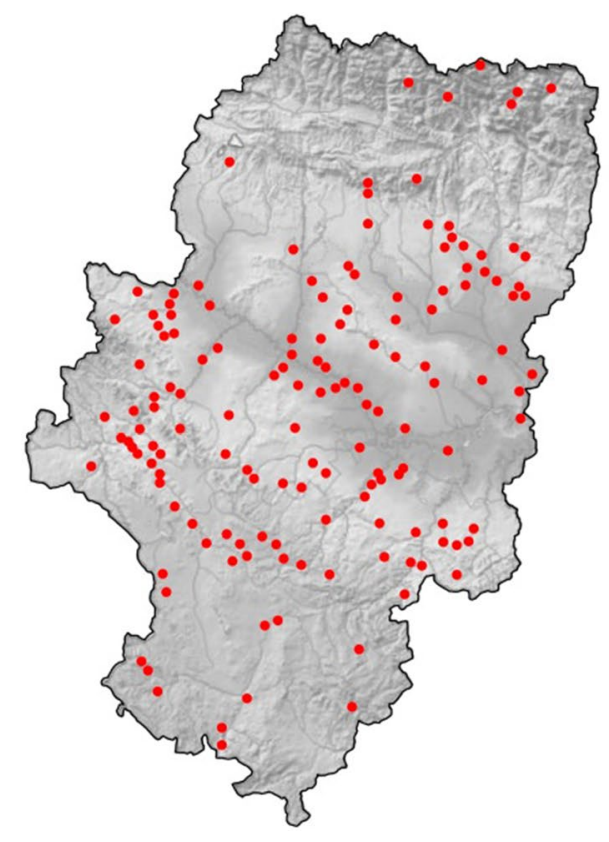

to identify municipalities that had/have historic or active quarries, kilns, and gypsum manufacturers. In addition, local Aragonese cadastral databases were used to locate streets, squares, and other places with terms related to gypsum production such as "Camino de las Yeserías" and "Calle de los Aljezares." The following Spanish terms were included in the toponymic search: "yeso," "aljez," "cheso," "yesería," "aljecería," "aljezar," "aljecera," "chesería," "yesero," and "estuco" (plaster). Note that the term "yeso" comes from the Greek word "gypsos" and "aljez" from the Andalusi Arabic word "al-ğișṣ." Furthermore, geological maps (La Spina 2016) showing the locations of gypsum outcrops were overlayed onto a map of the Aragonese municipalities in order to identify those municipalities with a high probability of historic or active gypsum production and use. Overall, 147 municipalities were visited and 89 of those were documented bibliographically (Fig. 2). In addition, 134 historic/ active quarries were located (i.e., today three industrialized quarries operate in Cuarte de Huerva (Zaragoza), Gelsa (Zaragoza), and in Calanda (Teruel), and one quarry continues to mine and produce traditional gypsum in Albarracin (Teruel)) and 61 historic/active gypsum processing sites documented. Furthermore, 81 former construction workers (active between 1935 and 1980) and company owners were interviewed (i.e., recorded semi-structured interviews), who provided detailed descriptions of the gypsum manufacturing process.

In order to verify the information obtained through the bibliographic review and local visits, calcination of gypsum in two traditional kilns was carried out in close proximity to the historic quarry of Navarrete (Teruel 2016). Gypsum extraction, assembly of the furnace, collection of firewood, firing, and gypsum grinding, were all done following traditional methods under the supervision of four former masons ${ }^{1}$ and documented photographically. The mineralogical composition of calcined and hydrated gypsum was determined using X-ray diffraction analysis (XRD, Model X'Pert PRO, PANalytical B.V., The Netherlands). Equipment settings: $\mathrm{Cu}-\mathrm{K} \alpha$ radiation, $\mathrm{Ni}$ filter, $45 \mathrm{kV}$ voltage, $40 \mathrm{~mA}$ intensity, $3^{\circ}$ to $60^{\circ} 2 \theta$ exploration range, and $0.05^{\circ} 2 \theta \mathrm{s}^{1}$ goniometer speed. Phase identification and quantification, as well as the determination of the crystallite size (applying the Scherrer equation), were performed using the XPowder software (Martin 2004).

\section{Results}

\section{Chronological timeline of the use of traditional gypsum in Aragon}

During prehistoric times, several important settlements existed in close proximity to large gypsum outcrops in Aragon. However, the only reported use of gypsum dates back to the Late Bronce Age/Iron Age $\left(9^{\text {th }}-\right.$ sixth century BC) in the archeological site "El Cabezo de la Cruz de la Muela" (41 ${ }^{\circ} 29^{\prime} 36.9^{\prime \prime} \mathrm{N}, 1^{\circ} 4^{\prime} 13.2^{\prime \prime} \mathrm{W}$ (archaeological site) google maps) in the province of Zaragoza (Picazo Millán and Rodanés Vicente 2009), and it has been impossible to obtain information regarding the prevailing gypsum technology during this period.

\footnotetext{
1 Personal communication, E. López, A. Meda, J. Rodrigo and I. Lechón (Navarrete (Teruel) 2016).
} 
The Romans (first century BC-fifth century AD) founded several important settlements in Aragon including Bílbilis (close to Calatayud, Zaragoza, $41^{\circ} 24^{\prime} 34.9^{\prime \prime} \mathrm{N}, 1^{\circ} 36^{\prime} 28.4^{\prime \prime}$ W (archaeological site) google maps), Celsa (close to Gelsa, Zaragoza, 41 ${ }^{\circ} 22^{\prime} 26.9^{\prime \prime} \mathrm{N}, 0^{\circ} 25^{\prime} 58.7^{\prime \prime} \mathrm{W}$ (archaeological site) google maps), and the Roman villa Loma del Regadío (Teruel, 41 ${ }^{\circ} 11^{\prime} 38.2^{\prime \prime} \mathrm{N}, 0^{\circ} 29^{\prime} 39.2^{\prime \prime} \mathrm{W}$ (archaeological site) google maps). In all of them, materials with high gypsum content have been identified, which were used for mortars, renders, and pavements (Alloza Izquierdo and Marzo Berna 2005). This is not surprising since all settlements were in close proximity to important gypsum outcrops, some of them exploited by multinational gypsum manufacturers (Pladur Gypsum S.A.U. and Saint-Gobain Placo Ibérica, S.A) at present. According to Kuntze (2009), Romans were the first to differentiate between gypsum and lime plasters and used the former extensively for indoor applications. Remarkably, compared to lime, little mention about the architectural use of gypsum is made in classical texts of this period. Pliny the Elder made an only brief remark on gypsum for architectural decorations in his "Historiae Naturalis" and Vitruvius included a very short comment on the use of gypsum for finishing purposes in the chapter about renders in his work "De architectura," while describing lime technology and the architectural use of lime in great length.

The presence of the Visigoths ( $5^{\text {th }}$-eighth century AD) as the ruling class, representing only $5 \%$ of the total population, did not seem to have had any important influence on the popular architecture in Aragon. According to Orlandis (Orlandis Rovira 2003), the general population maintained Roman customs including the prevailing catholic religion and the Latin language. Based on architectural examples of this period, including the Visigothic church of Santa María de Melque (Toledo), which reveals an important influence of the Roman architecture, it can be hypothesized that the construction technology did not suffer significant changes either (Caballero Zoreda et al. 1999).

During the early period of the Islamic governance ( $8^{\text {th }}$-tenth century AD), the ruling Spanish-Visigothic family was kept in power after converting to Islam (Cañada Juste 1980). According to Simonet (1886), during this period, 90-95\% of the population in Aragon were "Mozarabic" (i.e., an appellation for the inhabitants of Al-Andalus who upheld Roman customs), which makes it seem likely that the local traditional construction techniques were maintained. However, over time the proportion of the Islamic population, many of Yemeni descent (i.e., Arab dinasties Banu Tuyib and Banu Hud), increased substantially and by the middle of the eleventh century the "Mozarabs" only accounted for $50 \%$ of the total population (Souto Lasala 1992). During this second period of the Islamic governance $\left(10^{\text {th }}\right.$-twelfth century AD), Muslim settlers built new neighborhoods and municipalities (e.g., Calatayud and Daroca in Zaragoza, and
Albarracín in Teruel), introducing urban planning and construction techniques typical of the architecture of the Middle East (Corral Lafuente and Peña Gonzalvo 1986). Consequently, gypsum became an important building material for finishing and structural purposes including columns, pillars, mortar joints, structural walls, plastering, façade cladding, and flooring (Almagro 1986). During local visits, it was possible to establish that in all municipalities founded during this period, gypsum played an important role as a construction element. Despite the extensive architectural use of gypsum during this period, no technical documentation could be located, but many words of Arabic origin related to gypsum technology have remained in use since then.

The Islamic governance ended in Zaragoza in $1118 \mathrm{AD}$ with the reconquering by the Christians, and the following centuries $\left(12^{\text {th }}\right.$-seventeenth century AD) were characterized by the coexistence of the Islamic and Christian culture until the expulsion of the Islamic population in 1610, which affected about $1 / 6$ of the total residents (Pons 2009). Previous to their expulsion, the Islamic population either converted to Christianity (Moriscos) or maintained their Muslim religion (Mudejars); many of them working in construction related trades, upholding Islamic construction techniques and systems. The Islamic influence in the Christian architecture of this period is exemplified by the churches of San Gil and Santa María Magdalena in Zaragoza (Igea Romera 2011). During local visits, it was possible to verify that gypsum was an important constructive element in churches as well as other important monuments of this period such as the Ayyub Castle (Calatayud, Zaragoza), and the mudejar tower of San Martín (Teruel). Remarkably, several contemporary public records describe, under the term "mulleres," the specific construction work carried out by women, who were in charge of cleaning the construction site and transporting materials as well as preparing adobe. According to a public document from 1387 (García Herrero 2008), women were also hired to prepare gypsum mortar/plaster (given the name "masseras de algenz") and paid higher wages than common laborers. Another historic document from 1570, "The twenty-one books of the mills and machines" (Los Veintiún Libros de los Ingenios y Máquinas; Turriano 1996), gives a detailed account of the typology of gypsum kilns, as well as of tools used for gypsum processing (Fig. 3). This document written before the expulsion of the Moriscos is of special interest, considering that it gives testimony of the integration of traditional Islamic construction methodologies involving the use of gypsum in the local Aragonese architecture.

The following centuries $\left(17^{\text {th }}\right.$-nineteenth century AD) were marked by an extreme hardship for the Aragonese population as a result of economic destabilization, spread of diseases, and wars, which caused a regional depopulation and seemed to have hindered any significant advances in the field of construction. Evidence for the continued 
Fig. 3 Drawing of historic kilns and tools for gypsum processing (image courtesy of the Biblioteca Nacional de España [35])

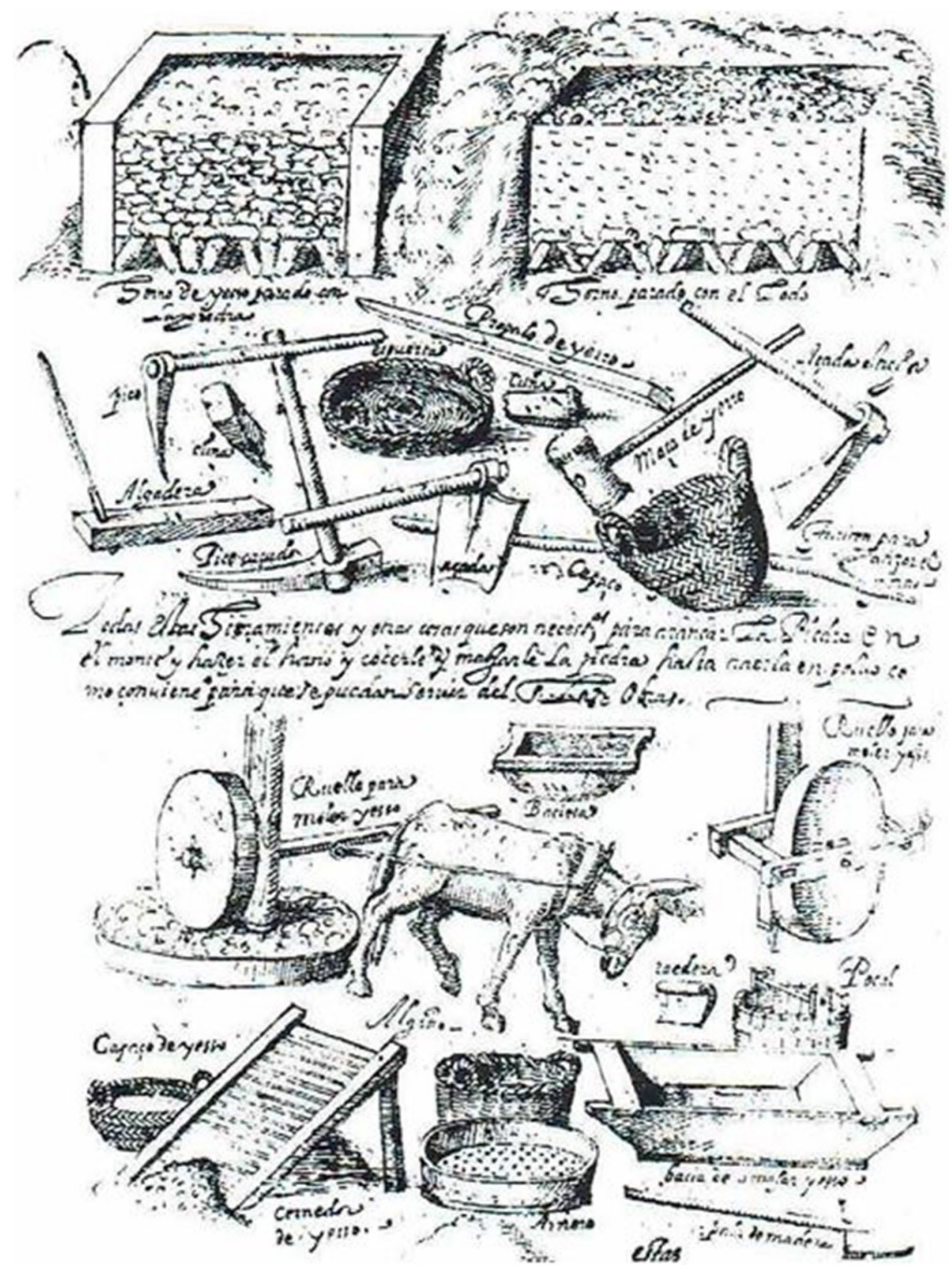

use of gypsum during this period is brought about by a detailed account of the organization of the gypsum manufacturers and plasterers in Zaragoza at the end of the eighteenth century (Expósito Sebastián 1985). According to this account, letters were sent to the "Real Sociedad Económica" and the Zaragoza City Council in 1782 and 1796, respectively, in which allegations regarding the poor gypsum quality were made. Remarkably, these letters still contained Arab terminology such as "aljecero, aljez, and almutazaf." A treatise from the same time period narrates the hard work of crushing the gypsum rock. According to Francisco Xavier Cid (Álvarez Barrientos 1988), it was customary in many towns in Aragon to hire a piper to play a melody that set the pace for raising and lowering the mallet and ease the work of the laborers. The monastery in Santa Fe (Zaragoza) built in 1739 and the Charterhouse (Cartuja de Nuestra Señora de las Fuentes) in Sariñena (Huesca) built in 1745 give testimony of the extensive structural use of gypsum for load-bearing walls, floors, masonry mortar, and renders as revealed by local visits. However, the eighteenth and nineteenth centuries were also marked by a slow introduction of modern building materials such as Portland cement and steel (Sanz Arauz and Villanueva Domínguez 2004). 
The beginnings of the twentieth century were prosperous with important advances in the Aragonese infrastructure. However, the Spanish Civil War (1936-1939) plunged the region into a state of absolute poverty. Communication between many municipalities in Aragon was still difficult, and the transport of goods on often unpaved roads relied on animal-drawn carts. Most municipalities did not yet have basic services, neither an electricity or water supply network, nor sanitation. Consequently, the construction techniques of the popular architecture in rural areas hardly advanced and remained basically unchanged, adapting existing buildings using low-budget solutions and locally available materials, including gypsum. ${ }^{2}$ Local visits allowed the identification of several constructions of this period, mainly animal shelters and agricultural warehouses, which revealed extensive use of gypsum as structural building material.

After the Civil War, Spain's industrialization accelerated and the road network and electricity grid were expanded between 1940 and 1970. Aragon experienced an important change in the traditional exploitation system of gypsum, originally based on small familyoperated businesses, which now transformed into local micro-companies. Today, numerous industrial ruins give testimony of the failed family-owned businesses (see the "Gypsum kilns" section), which had to close down during this period. According to Arredondo (Arredondo 1969), in 1963 gypsum companies had to produce 100 tons/day to be profitable, obligating manufacturers to adopt innovative production methods to improve productivity. At this time, gypsum had largely been replaced by Portland cement for structural uses. However, in rural areas, a preference for gypsum still persisted as access continued to be difficult in many remote villages, making the transport of industrial materials such as Portland cement very costly.

After 1970, companies had to further ramp-up production in order to stay competitive and pre-industrial furnaces soon became obsolete and were replaced by industrial furnaces. Local micro-companies eventually gave way to multinational companies (Saint-Gobain Placo Ibérica, S.A., Spain and Knauf Gips KG, Germany) that produce more than 1000 tons/day in each of their facilities. Today, the consumption of gypsum in the construction sector is greater than ever in volume, but its use is limited to interior cladding, and Portland cement and occasionally lime have completely replaced gypsum in structural applications.

\footnotetext{
2 Personal communication, M. Malo (Pozuelo del Campo-Morenilla (Teruel) 2017), J. García (Bara (Huesca) 2018).
}

\section{Evolution of the gypsum technology during the twentieth century}

The information obtained through field work, local visits, and the bibliographic review allowed a detailed description of the traditional gypsum technology and its industrialization during the twentieth century.

\section{Extraction process}

Local visits evidenced that, whenever possible, the extraction site, kiln, and grinding area were organized in such a way as to take advantage of the sloped landscape to facilitate the transport ${ }^{3}$ of the gypsum blocks and calcined material (i.e., the kiln and the grinding area were located below the gypsum quarry, Fig. 4a). About $90 \%$ of all traditional gypsum quarries studied was exploited through surface mining in Aragon (Fig. 4b). In a few municipalities (i.e., Villaba Alta and La Fresneda (Teruel) as well as Aladrén and Sastago (Zaragoza)), gypsum was extracted in underground mines (room and pillar mines), leaving behind large caves with a height and depth of up to 4 and $100 \mathrm{~m}$, respectively (Fig. 4c). Often numerous mines can be found in the same municipality, either belonging to a single or several families. ${ }^{4}$

During the first phase of the extraction process in open-pit mines, an about 1-1.5 m thick surface layer of powdery gypsum, which had suffered degradation due to meteorological actions, was removed using a hoe ${ }^{5}$ (Fig. 5a). The next layer, consisting of low density, brittle gypsum rock was commonly also discarded or, in some cases, used as an aggregate for gypsum mortars. The underlying layer of compact gypsum rock was traditionally extracted using a large gimlet and a pick to create a hole, in which a digging bar was inserted (Fig. 5b and c). This digging bar was used as a lever to extract large blocks of gypsum. According to experienced miners, a characteristic noise similar to a "snorting noise" anounced the separation of the block. Often the extraction process was facilitated by nailing wedges into the gypsum rock along the separation line with a mallet (Fig. S1a-d, Supplementary Material).

Between the 1930s and 1940s, mine workers started to use dynamite, ${ }^{6}$ which was inserted into the holes

\footnotetext{
3 Personal communication, L. Marcén (Leciñena (Zaragoza) 2014), J. Juan (San Mateo de Gallego (Zaragoza) 2017).

4 Personal communication, P. Mercado (Ricla (Zaragoza) 2019), J. Yague. (Tauste (Zaragoza) 2019).

5 Personal communication, J. Paracuellos (Bañón (Teruel) 2016).

${ }^{6}$ Personal communication, M. Zardoya (Borja (Zaragoza) 2020), R. Celma (La Fresneda (Teruel) 2019).
} 
Fig. 4 Gypsum mines: a abandoned gypsum production site in Navarrete (Teruel) showing (1) the extraction site, (2) kiln, (3) grinding area, and (4) building used for storage and sale; $\mathbf{b}$ open-pit mines in Villamayor (Zaragoza); and $\mathbf{c}$ underground gypsum mine in Villalba Alta (Teruel)
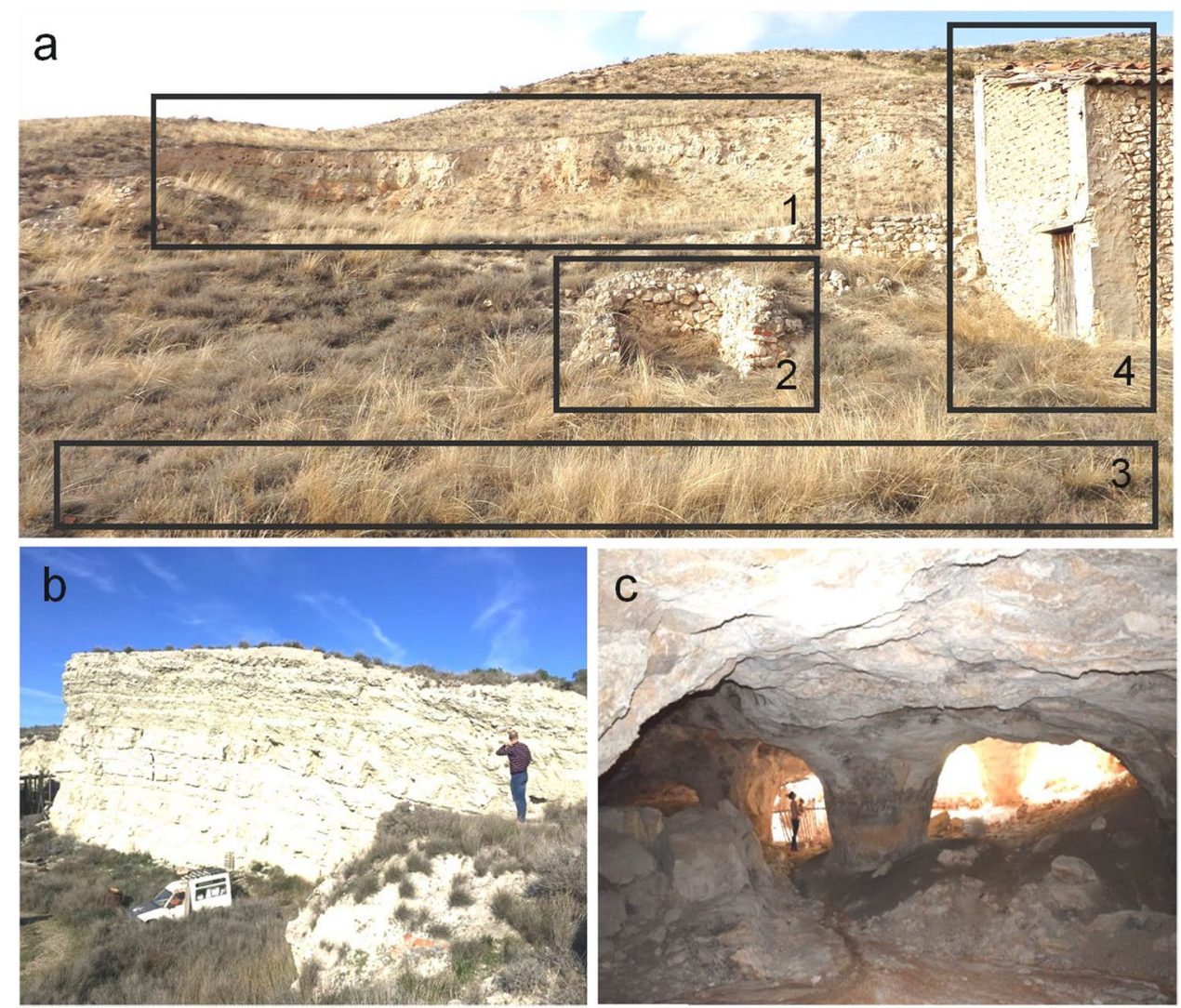

drilled with the gimlet in order to expedite the extraction process. The minework was further eased by the use of backhoes, which were introduced around the same time. Commonly, large gypsum blocks were extracted from the quarry, which were later divided into smaller pieces. Gypsum has a lamellar structure due to its sedimentary nature. Experienced miners knew how to use the planes generated by the lamellar structure in order to extract large blocks and break them down into smaller pieces without much effort (Fig. 5d and e).

\section{Transport of gypsum rock to the kiln}

Geographical particularities affected the mode of transportation. In many cases, it was not necessary to transport the material, since the gypsum was calcined in kilns located at the foot of the quarry. However, occasionally gypsum calcination was performed at the construction site. For longer distances, stretchers (Fig. 6a) and carts pulled by donkeys or mules (Fig. 6b) were used. In a few smaller municipalities, located at greater distance from gypsum quarries, subsidence-based calcinations were performed once or twice a year by farmers or masons. According to the testimony of former local workers, gypsum stone was collected over an extended period of time and stored until the amount necessary to fill an entire kiln was achieved. ${ }^{7}$ This way, gypsum calcination did not interfere with the farmers' main activities and bagging of the final product was unnecessary because it was immediately used on the construction site.

\section{Gypsum kilns}

Until the 1940s, mainly two different types of kilns were traditionally used in Aragon, namely, a circular (type A) and a rectangular kiln (type B). The former type (Fig. 7a; Fig. S2 and S4, Supplementary Material) was rarely used but has been identified in a few municipalities with very low gypsum demand, where only one or two kilns were fired per year. Rectangular kilns were the most frequently used type in all Aragonese provinces (Fig. 7b; Fig. S3, Supplementary Material). Remarkably, the design of these rectangular kilns did not seem to have changed over time, being identical to that documented in "The twenty-one books of the mills and machines" from 1570 (Turriano 1996). The preference for rectangular kilns seems peculiar to the Aragon regions, whereas in the rest of Spain circular kilns were much more common (La Spina and Grau Giménez 2020b). Generally, the kiln, also called

\footnotetext{
7 Personal communication, U. Grasa (Bara (Huesca) 2018), E. Bordonaba (San Mateo de Gallego (Zaragoza) 2017).
} 
Fig. 5 Gypsum extraction: a removal of powdery gypsum in Navarrete (Teruel); b extraction of a gypsum block using a large gimlet, pick, and wedges; c historic photography showing surface mining of gypsum in 1940 using picks and a digging bar in a family-owned quarry in San Esteban de Litera (Huesca) (photo courtesy of the "Centro de Estudios Literanos" in Huesca); $\mathbf{d}$ and e separation of a large gypsum block along the plane generated by the lamellar structure of the rock using a pick
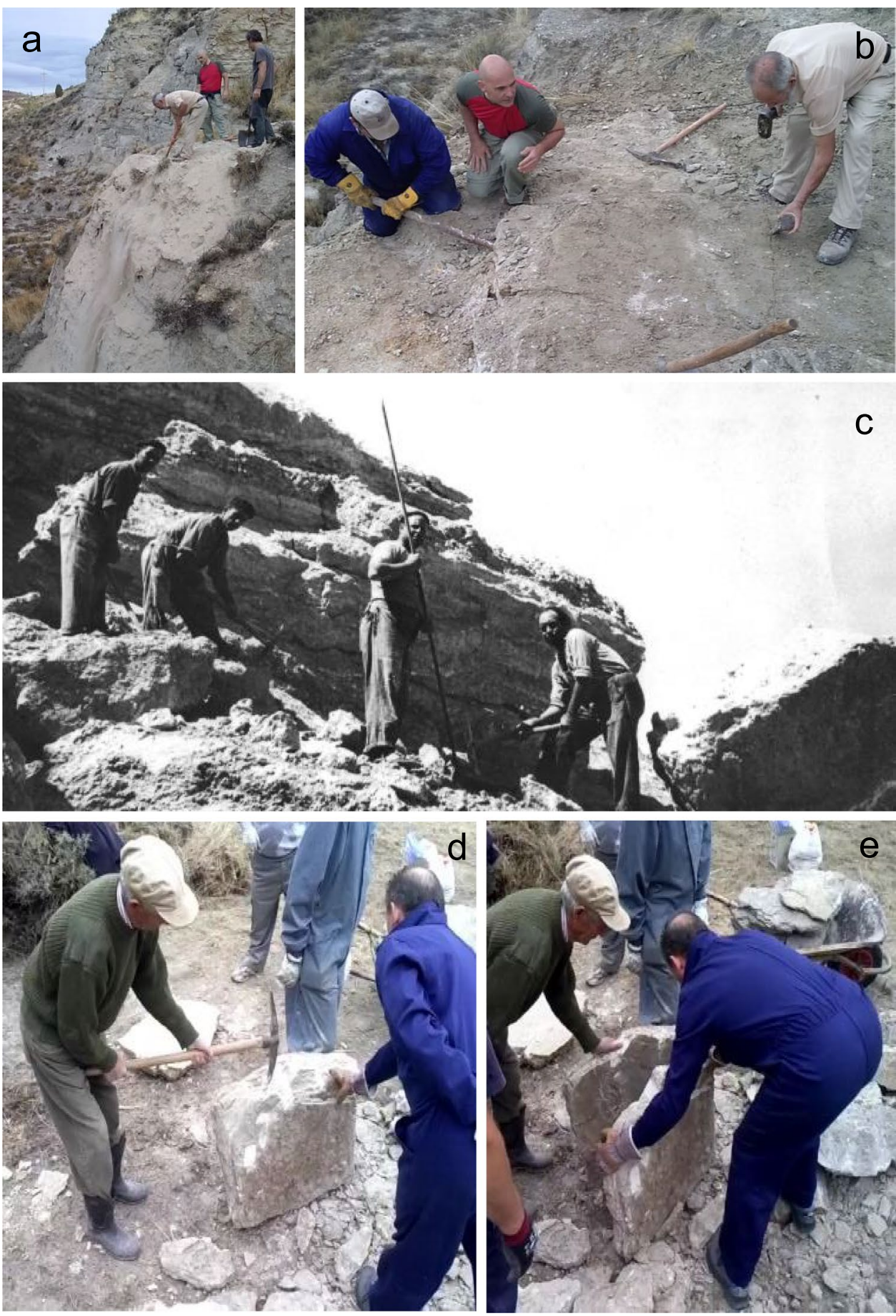

"hornete" (oven) or "casa" (house), was integrated in the terrain, often taking advantage of changes in the ground level due to quarry excavations. This way, the filling of the kiln could be done from the top, while the emptying was done from the bottom, which facilitated the process by force of gravity. In order to obtain greater stability, the excavated perimeter was always made up of a stone wall in the shape of the oven. Normally, gypsum blocks were used, although more fire-resistant lime or sandstone was preferred, depending on availability.

Circular kilns had a base with a diameter of 1-2 m (Fig. S2a-c, Supplementary material) and allowed for a relatively small load of $\sim 3.5 \mathrm{~m}^{3}$ of gypsum, therefore requiring less firewood than larger rectangular kilns. Gypsum blocks were laid in successive courses following the perimeter of the kiln until a small hollow dome was formed. Once the dome was completed, successive layers of gypsum blocks 
Fig. 6 Transportation systems: a remains of an antique stretcher (Borja, Zaragoza) and b cart filled with gypsum rock in (Lanaja, Huesca) in 1994 (photo courtesy E. Monesma Monge)
Fig. 7 Traditional kilns: a abandoned circular kiln (type A, Bara, Huesca), and b rectangular kiln (type B, Leciñena, Zaragoza); c and d schematics and photographic images of rectangular kilns (type B) used for experimental calcinations, showing the two stone laying variables using either large gypsum slabs as lintels (c) or successive courses of smaller gypsum blocks (d) to create the vault
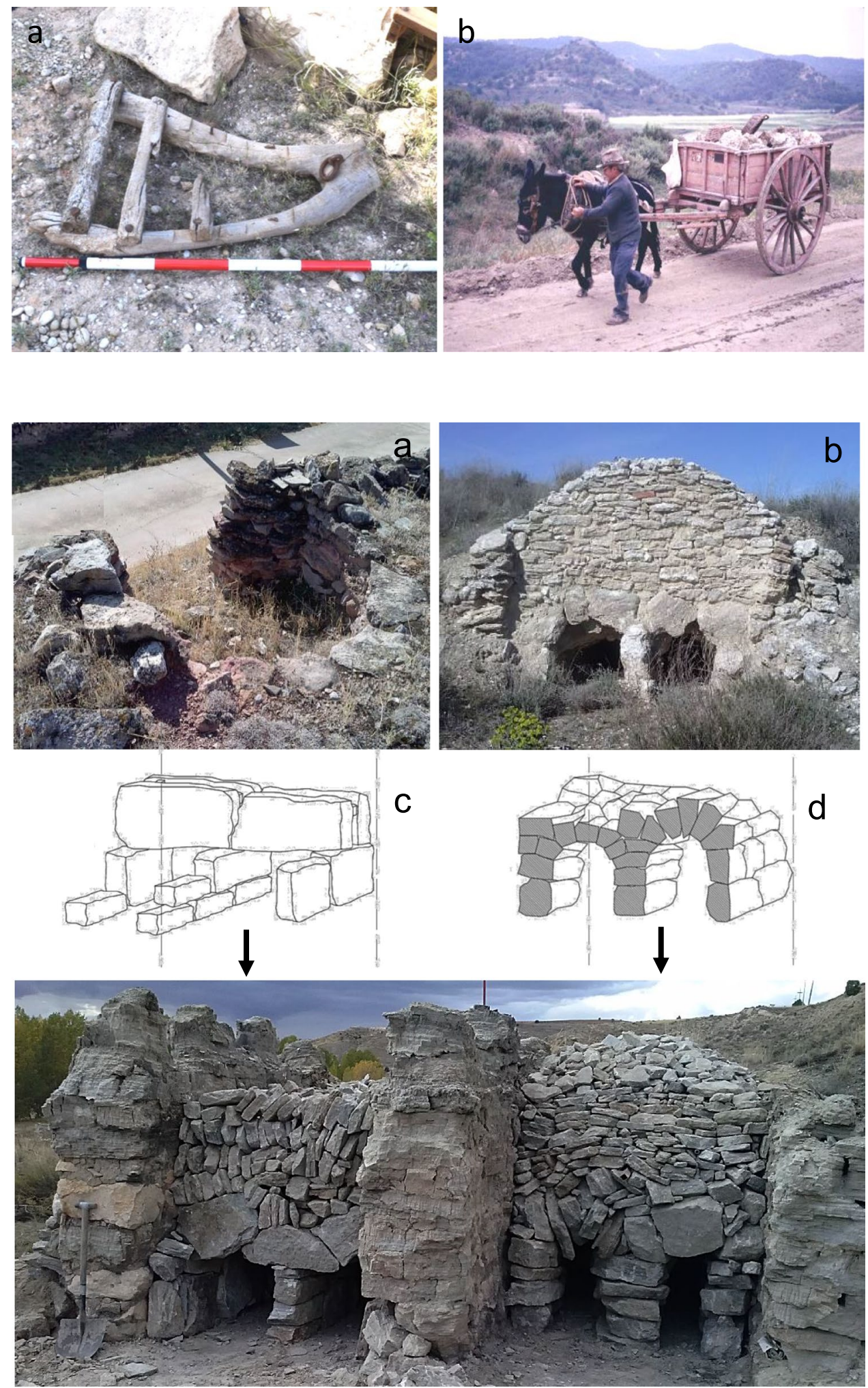

were carefully placed on top of the dome to fill the kiln, while avoiding damaging the vault. A communication hole (mouth) between the hollow vault of the dome (combustion chamber) and the exterior served to introduce the firewood.
Experienced workers were able to load the kiln by taking the shape of each individual gypsum block into consideration. Thus, hardly any further preparation of the gypsum blocks was unnecessary and very little "waste" was produced. 
Fig. 8 Abandoned historic kilns: a type $\mathrm{C}$ located in Tauste (Zaragoza), b type E located in San Esteban (Huesca), c type F located in Albelda (Huesca), and $\mathbf{d}$ operating cylindrical rotary kiln (type $\mathrm{G}$ ) located in Cuarte de Huerva (Zaragoza)
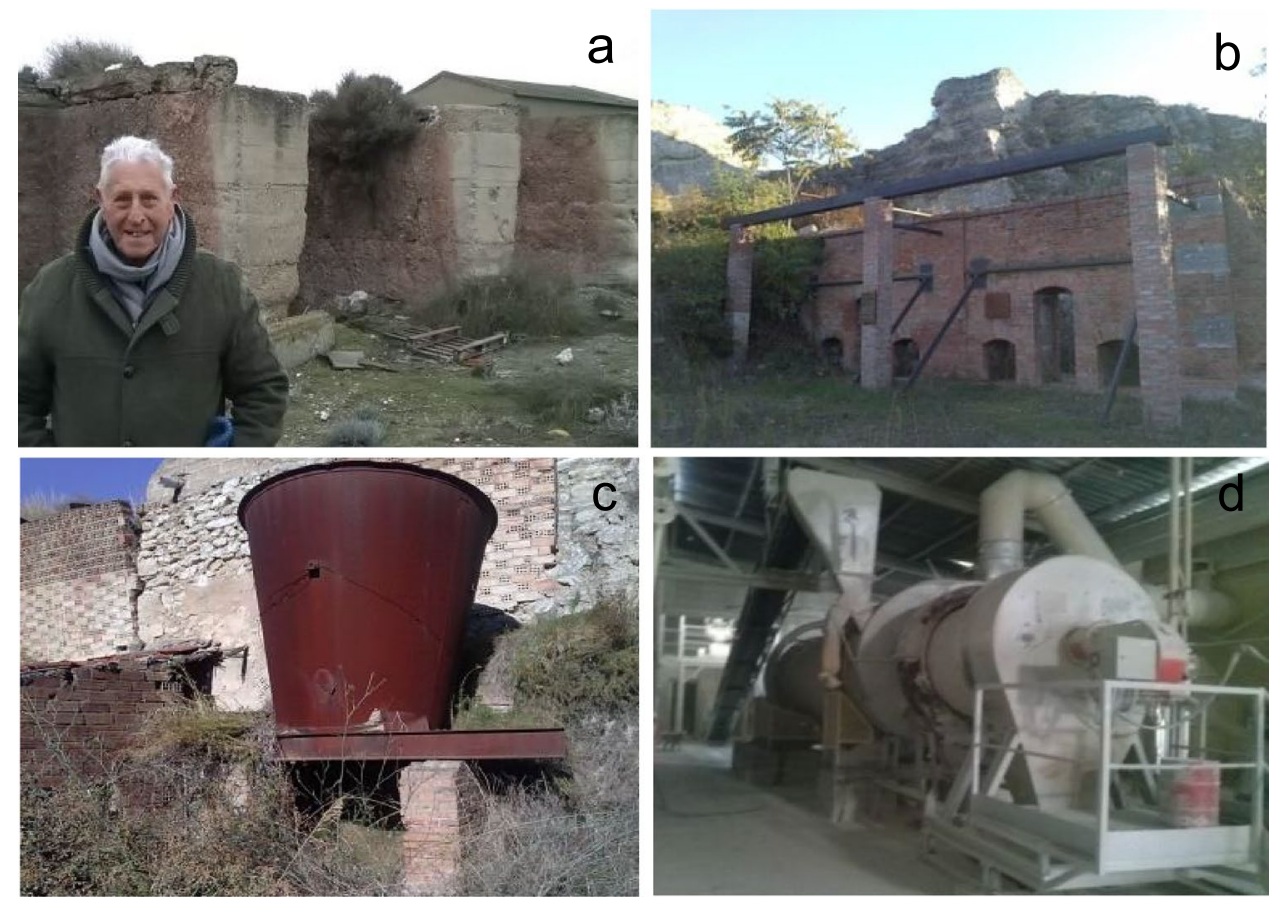

Larger blocks were generally placed closer to the fire, since they required higher temperatures to calcine completely, and had to withstand higher temperatures and greater weight.

Widely used rectangular kilns (commonly $3 \mathrm{~m}$ deep, $2.5 \mathrm{~m}$ wide, and $2 \mathrm{~m}$ high, Fig. 7b-d) were often carved into the slope of a hillside and could accommodate loads of $\sim 14 \mathrm{~m}^{3}$, equal to $\sim 10$ tons of gypsum. Gypsum blocks were arranged to form longitudinal walls, leaving space for vaults which served as combustion chambers. The rest of the blocks were mounted on top of these walls until the kiln was completely filled. Until a height of $\sim 50 \mathrm{~cm}$ was reached, this process was done carefully in order to avoid damaging the vault. Afterwards, the loading of the kiln could proceed at a faster speed. Local visits revealed that two different approaches were used to build the mouth of the kiln, either using large gypsum slabs as lintels or successive courses of smaller gypsum blocks to create the vault (Fig. 7c and d). The use of large gypsum slabs normally required the introduction of smaller gypsum fragments to separate the lintels and permit the venting of the smoke. Remarkably, all kilns in one municipality had always the same type of mouth. The choice, however, did not seem to have been influenced by any practical consideration.

During the 1940s and 1970s, family-owned gypsum manufacturers improved traditional kilns in order to stay competitive. ${ }^{8}$ Initially, changes mainly involved an increase

\footnotetext{
${ }^{8}$ Personal communication, J. M. Seira (Albelda (Huesca) 2017), J. Viudas (San Esteban de Litera (Huesca) 2017).
}

in size and the use of more fire-resistant materials ${ }^{9}$ such as bricks and cement for the perimeter of circular or rectangular kilns (Fig. 8a and b; Fig. S4 Type C, D, and E, Supplementary Material). During this period, it was not uncommon to find kilns of different designs being used in the same municipality. In some cases, a permanent combustion chamber made of bricks was added, which allowed for faster loading of the kiln. Remarkably, the design of this type of kiln was very similar to that used for the firing of ceramics and has mainly been identified in municipalities with a longstanding tradition of ceramic production (i.e., Tauste and Juslibol (Zaragoza), La Fresneda (Teruel), and San Esteban de Litera (Huesca)). A more evolved kiln has been located in Albelda (Huesca), denominated type F (Fig. 8c, Fig. S4, Supplementary Material). This kiln had of metal deposit above the combustion chamber and unloading was done using a cart, which could be positioned beneath the metal deposit. However, since the 1970s, cylindrical rotary kilns (type G, Fig. 7d; Fig. S4, Supplementary Material) were commonly used, which had the highest output and allowed combustion gases and ashes to be separated from the gypsum, this way obtaining a whiter product. Rotary kiln only permitted the use of gypsum rock pieces of up to $35 \mathrm{~mm}$, which had to be sieved prior to loading.

\footnotetext{
9 Personal communication, J. Calvo (Zuera (Zaragoza) 2018), J. Pola (Tauste (Zaragoza) 2019).
} 
Fig. 9 Traditional combustion material: $\mathbf{a}$ and $\mathbf{b}$ preparation of scrub bundles ("fajos")
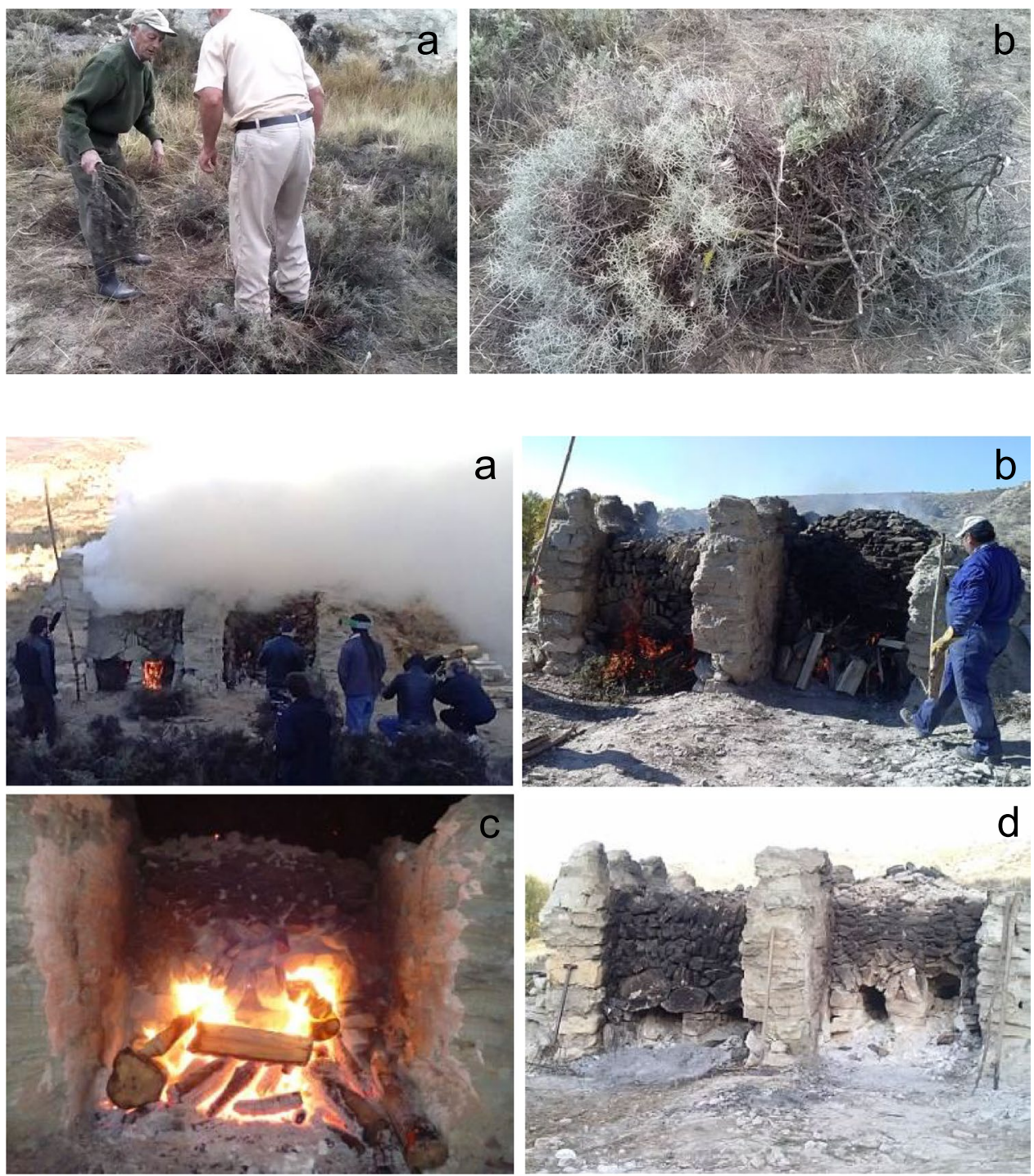

Fig. 10 Experimental gypsum calcination in two traditional kilns performed in 2016 using scrubs (left kiln) or firewood (right kiln): a dense, whitish smoke due to water release is generated during the initial calcination phase; $\mathbf{b}$ and $\mathbf{c}$ kilns during advanced stages of calcination, reaching a $T$ of up to $1100{ }^{\circ} \mathrm{C}$; and $\mathbf{d}$ traditionaI kilns during the cooling phase workers ${ }^{10}$ in the municipality of Navarete (Teruel), in the 1940s, a week's salary was required to buy the firewood for one kiln. Consequently, fast-growing shrubs, especially gorse, rosemary, and kernel, as well as agricultural residues (i.e., straw from cereals, corn, and almond shells), were used. Care was taken not to introduce soil into the combustion chamber, which would have affected the combustion. The volume necessary for the calcination of gypsum in a rectangular kiln was 200-300 "fajos" (bundles) of scrubs (Fig. 9). Each bundle weighs $\sim 15 \mathrm{~kg}$, amounting to $3750 \mathrm{~kg}$ of combustion material per calcination. According to experienced masons, ${ }^{11}$ the ratio of combustion material versus uncalcined gypsum was 1:3 by weight, independent of the type of combustion material. A continuous supply of

\footnotetext{
$\overline{10}$ Personal communication, E. López and I. Lechón (Navarrete del Rio (Teruel) 2016).

${ }^{11}$ Personal communication, A. Meda (Albarracín (Teruel) 2018).
} 
combustion material was required to maintain an adequate temperature until the calcination of gypsum was completed, which commonly took between 12 and $24 \mathrm{~h}^{12}$ (note that occasionally, calcination of up to $48 \mathrm{~h}$ is reported). Remarkably, some workers ${ }^{13}$ followed the moon phases in order to decide on the right timing for calcination, arguing that gypsum calcination was faster during waning moon due to benefical atmospheric conditions.

Gypsum $\left(\mathrm{CaSO}_{4} \cdot 2 \mathrm{H}_{2} \mathrm{O}\right)$ suffers a weight loss of about 15-20 wt\% due to dehydration upon calcination, which results in the formation of bassanite $\left(\mathrm{CaSO}_{4} \cdot 0.5 \mathrm{H}_{2} \mathrm{O}\right)$ and anhydrite $\left(\mathrm{CaSO}_{4}\right)$ (i.e., gypsum + heat $\rightarrow$ bassanite + anhydrite + water $\uparrow)$. Experimental calcinations in two traditional kilns using either scrubs or firewood showed that water release continued during the first 3-4 h of calcination, resulting in an extremely dense whitish smoke (Fig. 10a), which made continuous feeding of the kiln with combustion material very difficult for the workers. After $\sim 6 \mathrm{~h}$, the smoke becomes colorless (Fig. 10b and c), indicating that water was no longer released. At this point, workers could easily feed the kiln in a continuous manner. Datalogger measurements during our experimental calcinations revealed differences in the temperature evolution depending on the combustion material. Note that a minimum of 3 sensors was placed in the center of the kiln at different heights (Fig. S3, Supplementary Materials). During the initial phase, temperatures $\sim 150{ }^{\circ} \mathrm{C}$ were reached within the first hour in the scrub-fired kiln, while it took twice as long in the case of the wood-fired kiln to reach a similar temperature. However, after the initial phase, higher temperatures were reached using firewood (max. $T \sim 1100{ }^{\circ} \mathrm{C}$ ) compared to scrubs (max. $T \sim 750{ }^{\circ} \mathrm{C}$ ), which is not surprising considering the density of both combustion materials. Sanz Arauz (2009) recorded similar temperatures during traditional gypsum calcination in Albarracín (Teruel) and detected temperature variations between 200 and $1000{ }^{\circ} \mathrm{C}$ within the kiln.

The degree of calcination depends on the location of the gypsum blocks within the kiln, and it is virtually impossible to obtain a completely homogeneous material upon traditional calcination. In order to determine the completion of the calcination, workers commonly took gypsum samples from the upper part of the kiln, which were at the greatest distance from the combustion chamber and, thus, exposed to the lowest $T$. The degree of calcination was verified using organoleptic assessment methods, including a visual inspection of the gypsum color and compactness, ease of its disintegration, and observations regarding the color and smell of the smoke released during calcination. Some workers used straw, which had to ignite spontaneously

\footnotetext{
12 Personal communication, E. Durany (Albelda (Huesca) 2017), I. Murillo (Perdiguera (Zaragoza) 2014).

13 Personal communication, A. Meda (Albarracín (Teruel) 2018).
}

when in direct contact with the gypsum block to indicate a complete calcination. Once the calcination was completed, workers ${ }^{14}$ covered the upper part of the kiln with ash and the lower part with mud to ensure a gradual decrease in $T$. The cooling process commonly took between 2 and 3 days (Fig. 10d). According to experienced workers, ${ }^{15}$ faster cooling was generally avoided because it led to extremely fastsetting gypsum.

Changes in kiln size and design during the 1940s also affected the choice of combustion material. It became common practice in many municipalities to use low quality coal ${ }^{16}$ especially in kilns of type C, D, and E (Fig. S4, Supplementary Material). About $10 \mathrm{~cm}$ thick layers of coal were alternated with $20-40 \mathrm{~cm}$ thick layers of gypsum and ignited at the base. In this way, firing of the entire kiln load could be done without the need for constant feeding with combustion material. Remarkably, modern rotary kilns were often operated using firewood until the turn of the last century. Nowadays, gas is used for combustion, resulting in a reduction of labor costs related to feeding and removal of ash, and limiting contamination due to fumes. In modern rotary kilns, the temperature is closely monitored, resulting in an optimization of the calcination process by reducing time and temperature necessary to obtain a product of uniform quality. Commonly, $T$ does not exceed $\sim 180{ }^{\circ} \mathrm{C}$ in modern kilns, which has an important influence on the mineralogy of the final product. Bassanite is the main phase obtained during calcination in modern rotary kilns, whereas the traditional calcination process at much higher $T$ produces a multiphase product because the heat is not homogeneously distributed in the kiln (i.e., $\beta$-bassanite is formed at a $T=100-180^{\circ} \mathrm{C}$, soluble $\gamma$-anhydrite (anhydrite III) at a $T>180{ }^{\circ} \mathrm{C}$, and sparingly/unsoluble $\beta$-anhydrite (anhydrite II) at a $T>300 / 350{ }^{\circ} \mathrm{C}$ (Kuntze 2009; Newman 1941; Schmid et al. 2019). Experienced masons were aware of the influence of the calcination temperature on the final gypsum quality. However, Aragonese masons only rarely selected gypsum for particular applications based on its calcination temperature and rather mixed the calcined gypsum from different zones within the kiln to obtain a more or less homogeneous material. ${ }^{17}$ This is in contrast with findings based on the analyses of different historic gypsum mortars from other European countries (e.g., Italy, Poland, and Germany), which suggest the use of high-temperature gypsum (i.e., estrich gypsum) for particular application such as flooring, renders, and stucco decorations (Dariz and Schmid 2019;

\footnotetext{
${ }^{14}$ Personal communication, A. Millán (Albarracín (Teruel) 2016), J. Bello (Puebla de Hijar (Teruel) 2017).

15 Personal communication, J. Rodrigo (Burbaguena (Teruel) 2014).

16 Personal communication, E. Durany (Albelda (Huesca) 2017), R. Celma (La Fresneda (Teruel) 2019).

17 Personal communication, A. Meda (de Albarracín (Teruel) 2018).
} 
Kawiak 1991; Middendorf 2002). According to Freire et al. (2019), high-temperature gypsum was intentionally used in order to obtain a material with improved mechanical properties.

Preliminary results based on semiquantitative XRD analysis of the final product obtained during our experimental calcination revealed that the mineralogical composition depended on the combustion material and the location within the kiln. Note that calcined gypsum blocks from the center of the kiln at different heights were selected for XRD analysis. Several blocks from each zone were homogenized to obtain representative samples (Fig. S3, Supplementary Material). Calcination using scrubs as combustion material resulted in a multiphase product containing 70-95 wt\% anhydrite II and 5-30 wt\% bassanite (Fig. S5a, Supplementary Material). The use of firewood, in contrast, led to a material almost entirely composed of anhydrite II (Fig. S5b, Supplementary Material), which is consistent with higher temperatures measured in this kiln during calcination causing an almost complete dehydration of the gypsum. The determination of the crystallite size of the 020/200 Bragg peak of anhydrite provided additional information regarding the firing temperature within the kilns, as the crystallite size is closely related to the sintering temperature (Waje et al. 2010). In the case of the scrub-fired kiln, the crystallite size of the most intense anhydrite Bragg peak was almost constant (39-41 nm), suggesting that the average kiln temperature was fairly homogeneous. Consequently, small variations observed in the mineralogical composition among the samples from different zones were probably related to the size of the original gypsum blocks, as a higher degree of calcination is expected to be achieved in smaller blocks compared to larger blocks under identical conditions. In the wood-fired kiln, the crystallite size of the anhydrite 020/200 Bragg peak was the largest close to the combustion chamber $(71 \mathrm{~nm})$ and slightly smaller $(58-59 \mathrm{~nm})$ in zones further away from the fire, indicating that higher temperatures were reached in the case of the former. Overall, these findings are in agreement with the measured kiln temperatures, revealing a higher maximum temperature in the wood-fired kiln leading to a higher degree of sintering.

In addition, the calcined gypsum contained small amounts of quartz and trace amounts of clay and calcite, which are common impurities due to the presence of accessory minerals (Karni and Karni 1995). According to Vegas et al. (2010), the accessory minerals are beneficial because they might impart hydraulicity (i.e., calcite decomposes into $\mathrm{CaO}$ that can react with aluminosilicates and form hydraulic phases) to the product and improve strength and weathering resistance. Gypsum hydraulicity could be further enhanced if the gypsum is calcinated at very high $T$ (i.e., $1365{ }^{\circ} \mathrm{C}$; Newman 1941), resulting in the decomposition of gypsum into $\mathrm{CaO}$ and formation of hydraulic phases in the presence of clay minerals. Indeed, the presence of clay minerals might even reduce the decomposition $T$ of gypsum to $\sim 900{ }^{\circ} \mathrm{C}$ (La Spina and Grau Giménez 2020b).

Evidently, the calcination temperature also determines the mineral's ability to rehydrate (i.e., the calcined product is mixed with water to form dihydrate). It is known that calcium sulfate calcined above $\sim 200{ }^{\circ} \mathrm{C}$ becomes less reactive and consequently hydrates slower (Seufert et al. 2009). Farnsworth (1925) stated that in some cases, it might actually take 6 years for hydration of anhydrite to occur and Sanz Arauz (2009) suggested that delayed hydration could actually result in an increase in mechanical strength over time. However, sequential gypsum formation upon hydration could theoretically also lead to a disruption of the previously formed gypsum matrix and consequently result in strength decrease. In order to evaluate the hydration behavior of the calcined gypsum, it was mixed with water ( 0.4 water/solid ratio) immediately after cooling and applied in situ as a $\sim 10 \mathrm{~cm}$ thick render. Remarkably, a high degree of hydration was achieved in the case of both gypsum renders, which, according to XRD analysis, contained $\sim 85 \mathrm{wt} \%$ gypsum and $\sim 15 \mathrm{wt} \%$ anhydrite II, independent of the original mineralogical composition of the calcined gypsum (Fig. S5a and b, Supplementary Material). These results indicate that despite the relatively high temperatures during calcination, a large portion of the final product showed high rehydration capacity.

\section{Processing of the calcined gypsum}

Once the gypsum had cooled down, it had to be crushed and sieved. Traditionally, gypsum processing was done outdoors and the calcined product had to be protected from rain to avoid premature hydration. It was spread over a large flat surface and crushed manually using a simple wooden mallet or a specialized tool called "algadera" or "majadera" (Fig. 11a). If available, carts pulled by animals (Fig. 11b), stone rollers (often frustoconical), or mills (either special gypsum mills or mills used for olives or cereals) were used to facilitate grinding. The traditional grinding process resulted in a powder of heterogeneous granulometry. According to La Spina and Grau Giménez (2020a), part of the coarser fraction might not undergo hydration and can act as an aggregate. During the 1950s, mechanical crushers were introduced, which run on diesel and produced a much finer, homogeneous powder. According to the testimony of experienced workers, ${ }^{18}$ manual grinding was extremely hard work and the gypsum had to be well calcined to facilitate the crushing. Often

\footnotetext{
18 Personal communication, A. Meda (Albarracín (Teruel) 2016), J.
} M. Seira (Albelda (Huesca) 2017). 
Fig. 11 Gypsum processing: a crushing of gypsum using the traditional "algadera" (Lanaja (Huesca) photo courtesy of E. Monesma Monge); b gypsum crushing using a cart (San Juan de Plan (Huesca) in 1981 (photo courtesy of E. Monesma Monge)); c traditional sieving of gypsum, and $\mathbf{d}$ kneading of gypsum using a wooden

"bacia," which was also used as a measuring unit
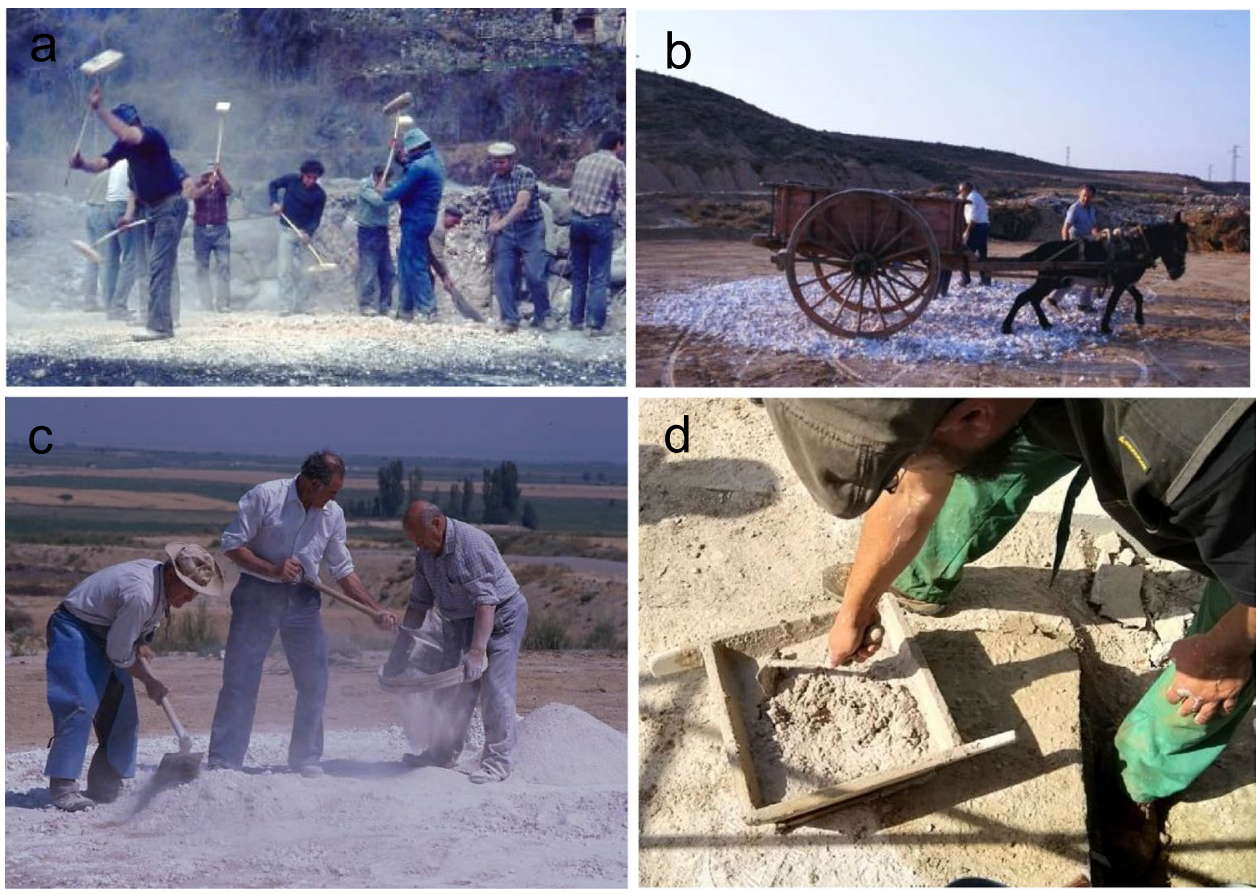

calcination was prolonged to obtain "overburned" gypsum, which was easier to crush. In the case of mechanical crushers, in contrast, the hardness of the calcined product is of lesser importance and gypsum calcination can be performed at lower $T$ and for shorter durations, consequently resulting in a reduction of production costs.

Traditionally, sieving was done considering the final purpose of the gypsum, ${ }^{19}$ finer powder being used for wall plastering and coarser fractions for flooring (Fig. 11c). According to A. Meda, ${ }^{20}$ a smooth plaster surface could not be achieved with the coarser fraction, but it was very suitable for flooring because a material with higher mechanical strength was obtained. Apart from sieves, workers used strainers and vibrating screens to separate the different fractions. Bagging and storage were not common before the 1950s. In many cases, the calcined gypsum remained in the kiln, which was covered with soil until construction work was under way. In some occasions, the calcined gypsum was "stored" in this manner for up to 3 years, because construction work was often performed by farmers and had to be adapted to their farming activities. Today, abandoned kilns containing uncalcined or even calcined gypsum can still be found in Aragon, giving testimony of the difficult economic situation of the gypsum industry in the rural areas of this region during the 1940 s-1970s.

\footnotetext{
19 Personal communication, J. Rodrigo (Burbaguena (Teruel) 2014), A. Millán (Albarracín (Teruel) 2016).

${ }^{20}$ Personal communication, A. Meda (Albarracín (Teruel) 2016).
}

Gypsum was sold in "cahiz," a Moorish measuring unit, which varied regionally (i.e., 1 cahiz equaled $690 \mathrm{~kg}$ in Madrid and $\sim 90 \mathrm{~kg}$ in some areas of Aragon). However, smaller measuring units, such as the "bacias" (wooden tray), were used as well (Fig. 11d). Noteworthy, the latter was also used for kneading.

\section{External factors influencing gypsum technology}

Local visits revealed that regional construction tradition, gypsum demand, and the accessibility of the municipality were key factors in determining the evolution of gypsum technology. In mountainous areas with extensive use of stone as construction material, gypsum demand was low because its use was limited to the filling of joints, pavements, and indoor plastering. Consequently, in municipalities such as Bara, San Juan de Plan, and Villanova in the province of Huesca as well as in Pozuelo del Campo and Villalba Alta in the province of Teruel, small circular kilns (type A) were used, which were typically only fired once or twice a year. In the plateau or valley areas, in contrast, soil was traditionally the preferred building material and stone was only used for specific building elements such as pillars, plinths, and decorations. Consequently, demand for gypsum was much higher, being used as mortars and renders for facades, floors, and various structural applications including load-bearing walls, pillars, ribs, vaults, and stairs.

Furthermore, some municipalities remained relatively isolated until the 1960 s and 1970 s as a result of limited accessibility (i.e., lack of access roads or remoteness of some municipalities). Consequently, traditional gypsum 
production in these municipalities kept basically unchanged. One of the most prominent cases in this respect is Albarracín (Teruel), where traditional gypsum is still being produced today and used as a render in local constructions and conservation interventions throughout Spain. This is in stark contrast to municipalities which supplied gypsum to other municipalities or even large cities. Local visits evidenced that San Esteban de Litera (Huesca) had been one of the most innovative municipalities in terms of gypsum technology (i.e., improvements in kiln design and testing of new combustion materials), bordering with Catalonia and supplying gypsum to large municipalities such as Monzón and Binefar (Huesca) or Balaguer (Lleida, Catalonia) during the 1940s to 1970s. Other municipalities in the province of Zaragoza that stood out for their innovations of the pre-industrialized gypsum production process were Zuera, Cuarte de Huerva, and Leciñena, which all supplied gypsum to a relatively large market as a result of their immediate vicinity to the city of Zaragoza.

\section{Concluding remarks}

The outcome of our study revealed that widespread use of gypsum for construction purposes (especially exterior and structural application) in Aragon can be directly related to the arrival of Islamic migrants, leading to a significant increase in the population towards the middle of the eleventh century and greatly furthering intercultural relations throughout the southern Mediterranean and the Near and Middle East, where the architectural use of gypsum had a longstanding tradition.

The first bibliographic reference regarding kiln types and specific tools for gypsum processing dates back to 1570 . Bibliographic research and local visits evidenced that gypsum technology underwent little changes, and identical kiln types and tools were still in use in Aragon until the second half of the twentieth century (i.e., documented in $70 \%$ of the visited municipalities). Considering the limited changes during this time, it seems very likely that the documented traditional kilns were not only in use since the sixteenth century but date back to the Islamic era, especially since almost identical traditional gypsum kilns are documented for the Middle East (Oudbashi and Shekofte 2008).

It can also be affirmed that until 1940, gypsum was almost exclusively produced in a traditional manner and only accelerated industrialization during the following decades led to a wider spread use of modern rotary kilns and automated processing techniques. Gypsum processing methods did not evolve in a homogeneous manner in Aragonese municipalities, key factors for the evolution of gypsum technology being accessibility and gypsum demand based on demography and preferred construction systems.
The bibliographic review revealed that an abundant amount of information exists regarding traditional gypsum technology in Aragon. However, many documents are published in local journals or web pages and have limited accessibility. Furthermore, local visits and interviews with current and former workers, manufacturers, and quarry owners were essential in order to gain a complete understanding of traditional gypsum technology.

Commonly, gypsum was exploited in Aragon through surface mining by manual extraction. Traditionally, gypsum was calcined at $T \leq 1100^{\circ} \mathrm{C}$, and subsequent grinding and sieving were performed manually. The obtained multiphase product had a heterogeneous granulometry and contained principally anhydrite, small portions of bassanite, and varying amounts of impurities including quartz, lime, and clay minerals. General agreement exists that the industrialization of the gypsum process had a drastic effect on the final gypsum quality, resulting in a fine-grained, homogeneous product primarily containing bassanite, which is generally considered unsuitable for exterior applications. Based on the analysis of historic mortars, many researchers concluded that the heterogeneous granulometry and the high content in soluble and insoluble anhydrite (leading to delayed hydration or acting as an aggregate in the case of insoluble anhydrite) and impurities such as lime and clay minerals (enabling the formation of hydraulic phases) are responsible for the superior weathering resistance and mechanical strength of traditional gypsum. However, so far, no systematic studies have been performed, which relate the mineralogical composition with textural features (porosity, crystal morphology and degree of interlocking, grain size, and presence of unhydrated binder lumps) in order to prove the aforementioned hypothesis. To fill this gap, research is currently underway, which focuses on the influence of the firing temperature on the textural and mineralogical evolution of calcined natural gypsum and its hydration products, considering the formation of hydraulic phases. In addition, separate studies are presently performed using reagent grade bassanite and additives (lime and activated clay minerals) in order to obtain further insights into the influence of the formation of hydraulic phases on the final properties of the hydrated product. The combined research outcome will advance current knowledge on gypsum technology and allow the formulation of compatible gypsumbased conservation mortars and plasters.

Supplementary Information The online version contains supplementary material available at https://doi.org/10.1007/s12520-021-01438-6.

Acknowledgements We thank all interviewees for sharing invaluable information on gypsum processing and application. We are also indebted to Félix Rivas, Dr. Carlos Rodríguez-Navarro, the Centro de Estudios del Jiloca, and the Asociación Territorio Mudéjar for their constant support. Analyses were performed at the Department of Mineralogy and Petrology of the University of Granada (Spain). 
Funding Funding for open access charge: Universidad de Granada / CBUA. This research was supported by the Research Group RNM-179 (Junta de Andalucia).

Data availability All data needed to evaluate the conclusions in the paper are present in the paper and/or the Supplementary Materials. Additional data related to this paper may be requested from the corresponding author (kelert@ugr.es).

\section{Declarations}

Competing interests The authors declare no competing interests.

Open Access This article is licensed under a Creative Commons Attribution 4.0 International License, which permits use, sharing, adaptation, distribution and reproduction in any medium or format, as long as you give appropriate credit to the original author(s) and the source, provide a link to the Creative Commons licence, and indicate if changes were made. The images or other third party material in this article are included in the article's Creative Commons licence, unless indicated otherwise in a credit line to the material. If material is not included in the article's Creative Commons licence and your intended use is not permitted by statutory regulation or exceeds the permitted use, you will need to obtain permission directly from the copyright holder. To view a copy of this licence, visit http://creativecommons.org/licenses/by/4.0/.

\section{References}

Alloza Izquierdo R, Marzo Berna P (2005) Los morteros antiguos. Kausis 3:46-52

Almagro A (1986) El yeso, material mudéjar. In:Actas del III Simposio Internacional de Mudejarismo, Instituto de Estudios Turolenses/ Centro de Estudios Mudéjares, Teruel, pp 453-457

Álvarez Barrientos J (1988) Música y medicina: Francisco Xavier Cid y su "Tarantismo observado en España" (1787). Rev Dialectol Tradic Pop 43:39-46

Arredondo F (1969) Estudio de materiales II. El yeso. Instituto Eduardo Torroja de la Construccion y del Cemento (C.S.I.C.), Madrid

Bel-Anzué P, Almagro A, Saez Pérez MP, Rodriguez-Navarro C (2017) Influence of the calcination process in traditional gypsum with structural behavior. Ge-Conservación 1:79-85

Berzosa C (1976) Análisis estructural del crecimiento económico español (1950-1959). PhD Thesis, Universidad Complutense Madrid

Caballero Zoreda L, Fernández Mier M, Rubinos Pérez A, Arnanz AM, López P, Macías Rosado R, UzquianoOllero P (1999) Notas sobre el complejo productivo de Melque (Toledo): prospección del territorio y análisis de Carbono 14, polínicos, carpológicos y antracológicos y de morteros. Arch Espanol Arqueol 72:199-240

Cañada Juste A (1980) Los Banu Qasi (714-924). Príncipe De Viana 41:5-96

Corral Lafuente JL, Peña Gonzalvo FJ (1986) La cultura islámica en Aragón. Editorial Luis Vives, Zaragoza

Dariz P, Schmid T (2019) Phase composition and burning history of high-fired medieval gypsum mortars studied by Raman microspectroscopy. Mater Charact 151:292-301

Elsen J (2006) Microscopy of historic mortars - a review. Cem Concr Res 36:1416-1424

Expósito Sebastián M (1985) El gremio de albañiles de Zaragoza (1775-1806). Artigrama 2:161-176

Farnsworth M (1925) The hydration of anhydrite. Ind Eng Chem 17:967-970
Freire MT, Silva AS, do Rosário Veiga M (2019) Stucco marble in the Portuguese architecture: first insights in mineralogical, physical and mechanical properties. In: Alvarez JI et al (eds) Proceedings of the 5th Historic Mortars Conference, RILEM Publications SARL, pp 211-225

Gárate Rojas I (1999) Artes de los Yesos: Yeserías y Estucos. Editorial Munilla-Lería, Madrid

García Herrero MC (2008) Actividades Laborales Femeninas a Finales de la Edad Media: Registros Iconográficos. In: LacarraDucay MC (ed) Arte y Vida Cotidiana en la Época Medieval. Institución Fernando el Católico, Zaragoza, pp 17-48

Herrero MJ, Escavy JI, Bustillo M (2013) The Spanish building crisis and its effect in the gypsum quarry production (1998-2012). Resour Policy 38:123-129

Igea Romera J (2011) Caracterización de los materiales de construcción del Mudéjar aragonés. Diseño de nuevos morteros para su aplicación en restauración. PhD Thesis, Universidad de Zaragoza

Karni J, Karni E (1995) Gypsum in construction: origin and properties. Mater Struct 28:92-100

Kawiak T (1991) Gypsum mortars from a twelfth-century church in Wiślica, Poland. Stud Conserv 36:142-150

Kingery WD, Vandiver P, Prickett M (1988) The beginnings of pyrotechnology, part II: production and use of lime and gypsum plaster in the Pre-Pottery Neolithic Near East. J Field Archaeol $15: 219-243$

Kuntze RA (2009) Gypsum: Connecting Science and Technology (MNL 67). ASTM International, Newburyport

La Spina V (2016) Estudio del Yeso Tradicional en España: Yacimientos, canteras, hornos y la arquitectura tradicional, su estado de conservación y propuestas de itinerarios visitables para su revalorización y difusión. Fase I y II. https://www.culturaydeporte. gob.es/planes-nacionales/planes-nacionales/arquitectura-tradi cional/actuaciones/estudio-del-yeso-tradicional-en-espana.html. Accessed 20 October 2020

La Spina V, Grau Giménez CJ (2020a) Uses of Gypsum in Spanish architectural heritage: typologies and some unique construction techniques. Int J Archit Herit 14:176-195

La Spina V, Grau Giménez CJ (2020b) La diversidad tipológica de los hornos tradicionales de calcinación de yeso en España. Inf De La Construcción 72:e334

La Spina V, Mileto C, Vegas F (2013) The historical renderings of Valencia (Spain): An experimental study. J Cult Herit 14:S44-S51

Le Dantec T (2016) Gypsum external renders of Paris: history and fabrication. In: Campbell J, Bill N, Pan Y (eds) Proceedings of the Third Annual Conference of the Construction History Society, Construction History Society, Cambridge, pp. 59-72

Lucas A, Harris JR (1962) Ancient Egyptian Materials and Industries. Edward Arnold, London

Marco LN (2002) Blancos "montes negros". Trébede: Mensual Aragonés de Análisis, Opin Cult 65-66:6-8

Martin JD (2004) Using XPowder: a software package for Powder X-Ray diffraction analysis (GR, 1001/04, ISBN 84-609-1497-6)

Middendorf B (2002) Physico-mechanical and microstructural characteristics of historic and restoration mortars based on gypsum: current knowledge and perspective: Special Publications 205. Geological Society, London, pp 165-176

Mileto C, Vegas F, La Spina V (2011) Is gypsum external rendering possible? The use of gypsum mortar for rendering historic façades of Valencia's city centre. Adv Mater Res 250-253:1301-1304

Newman ES (1941) Behavior of calcium sulfate at high temperatures. J Res Nat Bur Stand 27:191-196

Orlandis Rovira J (2003) Historia del Reino Visigodo Español: los Acontecimientos, las Instituciones, la Sociedad, los Protagonistas. Rialp, Madrid 
Oudbashi O, Shekofte A (2008) Traditional methods of gypsum production in province of Khuzestan, southwest of Iran In: Characterization, Diagnosis, Conservation, Repair and Compatibilit, $1^{\text {st }}$ Historical Mortars Conference (HMC08). Laboratório Nacional de Engenharia Civil (LNEC), Lisbon

Picazo Millán JV, Rodanés Vicente JM (2009) Los poblados del Bronce Final y Primera Edad del Hierro. Cabezo de la Cruz (La Muela, Zaragoza). Gobierno de Aragón, Dpto. De Educación, Cultura y Deporte, Zaragoza

Pons L (2009) Los moriscos. Conflicto, Expulsión y Diáspora, Los Libros de la Catarata, Madrid

Reichl C, Schatz M, Zsak G (2014) World Mining Data. Vol 32: Minerals Production. International Organizing Committee for the World Mining Congresses, Vienna

Riba Arderiu A, Macau Vilar V (1962) Situación, Características y Extensión de los Terrenos Yesíferos en España. Servicio Geológico de Obras Públicas, Ministerio de Obras Públicas, Madrid

Rodríguez-Navarro C (2012) Binders in historical buildings: traditional lime in conservation. Seminarios De La Sociedad Española De Mineralogía (SEM) 9:91-112

Sanz Arauz D (2009) Análisis del yeso empleado en revestimientos exteriores mediante técnicas geológicas, $\mathrm{PhD}$ Thesis, Universidad Politécnica Madrid

Sanz Arauz D, Villanueva Domínguez LD (2004) Albarracín y el yeso rojo. Inf De La Construcción 56:47-52

Schlütter F, Kaiser W, Juling H (2010) High fired gypsum mortar for screeds, terrazzo and masonry repair on historic monuments. Production, properties and sample applications. In: Válek J, Groot C, Hughes JJ (eds) 2nd Conference on Historic Mortars-HMC 2010 and RILEM TC 203-RHM final workshop, RILEM Publications SARL, pp. 1169-1180

Schmid T, Jungnickel R, Dariz P (2019) Raman band widths of anhydrite II reveal the burning history of high-fired medieval gypsum mortars. J Raman Spectrosc 50:1154-1168
Seufert S, Hesse C, Goetz-Neunhoeffer F, Neubauer J (2009) Quantitative determination of anhydrite III from dehydrated gypsum by XRD. Cem Concr Res 39:936-941

Simonet FJ (1886) Historia de los mozárabes en España. La Real Academia de la Historia, Tipográfico de la Viuda e Hijos de M. Tello, Madrid

Souto Lasala JA (1992) El poblamiento del término de Zaragoza:(siglos VIII-X): los datos de las fuentes geográficas e históricas. Anaquel De Estudios Árabes 3:113-152

Turriano J (1996) Los Veintiún Libros de los Ingenios y Máquinas. Ministerio de Cultural/Biblioteca Nacional de España, Madrid

Vegas F, Mileto C, Fratini F, Rescic S (2010) May a building stand upon gypsum structural walls and pillars? The use of masonry made of gypsum in traditional architecture in Spain. In: Jäger W (ed) Proceeding of the Eight International Masonry Conference. International Masonry Society and Technische Universität Dresden, Whyteleafe, pp 2183-2219

Waje SB, Hashim M, Yusoff WDW, Abbas Z (2010) X-ray diffraction studies on crystallite size evolution of $\mathrm{CoFe} 2 \mathrm{O} 4$ nanoparticles prepared using mechanical alloying and sintering. Appl Surf Sci 256:3122-3127

Wende U, Kozub P, Arnold T, Meinhardt J (2010) High-temperature gypsum plaster: Investigations into conservation and restoration of historic gypsum objects. In: Válek J, Groot C, Hughes JJ (eds) 2nd Conference on Historic Mortars-HMC 2010 and RILEM TC 203RHM final workshop. RILEM Publications SARL, pp. 1257-1264

Publisher's note Springer Nature remains neutral with regard to jurisdictional claims in published maps and institutional affiliations. 